\title{
8
}

\section{Nationality Redefined, or Lazy Macunaíma}

\begin{abstract}
Cooper and Alencar provide representative examples of how, in the nineteenth century, a literature of national identity began to be built in two new American nations. By the beginning of this century, affirming difference and defining nationality had become less critical for the United States as the nation's cultural and economic power grew. The early literatures of nationality in the United States and Brazil are easily comparable because the power relations between the United States and England, on one hand, and between Brazil and Portugal, on the other, were similar; so were the new nations' tasks of affirming national identity and claiming cultural parity with the former metropoles. In time, however, power relations between the United States and England (or Europe) changed. When the United States began to be a world power, its economic, military, and cultural influence was added to that which Europe (mainly France and England, but Portugal as well) still exercised on Brazil. The modernism of Mário de Andrade was therefore a continuation of the romanticism of Alencar in a way in which that of Ezra Pound, T. S. Eliot, or Gertrude Stein was not a continuation of Cooper's. The new literary idiom of Brazilian modernists expressed relations of power in terms similar to those of its predecessors in the previous century and continued to concern itself with defining nationality in reference to a powerful other.

But as before, these cultural products from the margin can also play a role in the ideological economy of the dominant cultures. The so-
\end{abstract}


called Boom of Latin-American literature reproduces within the Americas the relationship between more and less powerful but interconnected polities that obtained a century before between the two shores of the Atlantic. Mario Vargas Llosa and Gabriel García Márquez, translated into English or French, reach a wide public to whom they seem elemental and fresh; their realism is magical, in contrast to the humdrum variety grown domestically in Europe or the United States, and the primitive violence they write of is almost redemptive. They offer instant and automatic "estrangement" by using the language of power idiosyncratically.

In redefining nationality against external pressure, however, a work can also idiosyncratically subvert the schemes of interdependence in its own cultural environment. Macunaima (1928), by the Brazilian Mário de Andrade, problematizes the relation between national identity and foreign influence by estranging the exotic itself and blocking its formulation of national identity. The other against whom the self-definition becomes necessary is divided: an enviable and unavoidable political and economic power resides in England and the United States; France and Italy, as intellectual and artistic models, stimulate the creation of a language in which the confrontation can take place; and a German ethnologist provides the science, the raw data upon which the image of a national self is built.

Six years before the publication of Macunaima, Andrade had taken part in the "Week of Modern Art," held in the Municipal Theater of São Paulo. In that most conventional plush, red-and-gilt forum hired for the occasion by an editor of the respectable and widely circulated daily Jornal do comércio, there was bedlam. A full house chanted the refrains of unruly poetry by Manuel Bandeira, whistled and stomped at the dissonant music of Heitor Villa Lobos, gasped at disturbing paintings by Fernand Leger's student Anita Malfatti, and listened to Graça Aranha and Oswald de Andrade demolish established poets and literary figures. ${ }^{1}$ For the people involved in modern art, the Week was the culmination of years of experimentation and contacts with European movements such as dada, futurism, surrealism and with the works of Guillaume Apollinaire, Paul Verlaine, Stéphane Mallarmé, Emilio Mari-

\footnotetext{
${ }^{1}$ See Raul Bopp, Movimentos modernistas no Brasil, especially chapter 1, "Movimento modernista de 1922," for an eyewitness account of the week and further developments.
} 
netti, Emile Verhaeren, and others. ${ }^{2}$ In those few days the São Paulo rebels became the established avant-garde. Their works were published not only in little magazines brought out by themselves but in the literary pages of large newspapers such as Correio da manhã. Editors were sympathetic to these efforts to transform and renew artistic expression in Brazil and hoped they would propel the country out of its provincial corner into the larger world. Taking models from France and Italy, the Brazilian modernists were to transform expression to voice cultural and economic transformations modeled on those in England and the United States. ${ }^{3}$ In their work an authentic spirit of Brazilian nationality was to find a language characteristic of the nation and "legible"-if just barely-within the syntactic and semantic rules of the models. The task was possible because the models themselves were then open to that particular kind of renewal and willing to encourage it. French artists looked to African and other "primitive" art for inspiration, and the economically dominant nations were investing in "primitive" markets, whose rapid urbanization was seen, paradoxically and inevitably, as a desired sign of progress.

Macunaima draws up an account of these changes. It is written in the city of São Paulo, as coffee begins to enrich the state of São Paulo, attracting floods of national migrants and foreign immigrants and challenging older centers of national political power. In a history told from the point of view of progress, this change is seen, on the whole, as desirable. But Macunaima tries to find the continuity between modernization and a primitive substratum. It is a sophisticated act of trans-

\footnotetext{
${ }^{2}$ Meeting in Paris in 1913 with Tristão de Athayde and Rodrigo Otávio Filho, Graça Aranha urged them to renew Brazilian literature: "Do something new. Do something crazy." In 1922 Aranha was invited to give the keynote address at the Week. Members of the cultural and economical elite of São Paulo took regular trips to Paris and were acquainted with the artistic innovations of the time (Bopp, pp. 17n, 16). Mário de Andrade refused to join these pilgrims of culture and never left Brazil, but he had an enormous library and subscribed to a number of French journals, particularly L'esprit nouveau, of which he had the complete collection (see Gilberto Mendonça Teles, "L'avant-garde européenne," p. 106). Andrade's library, now in the care of the Instituto de Estudos Brasileiros of the Universidade de São Paulo, is being catalogued under the direction of Telê Ancona Lopez; from the catalog Nites Therezinha Feres documents Andrade's reading in contemporary French texts (Leituras em francês).

${ }^{3}$ Luis Alberto Moniz Bandeira, in Presença dos Estados Unidos no Brasil, documents the efforts of the United States to supplant England as the most important economic presence in Brazil. See chap. 28 in particular, for a discussion of the years when modernism was at its peak. See also Elizabeth Lowe, The City in Brazilian Literature, especially chap. 1 , for a discussion of the relation between urbanization and modernist literature in Brazil.
} 
culturation which at first garnered mixed reviews for its difficult, idiosyncratic language. Some readers were sympathetic, but even those who did not like it praised it for being "talented nonsense." ${ }^{4}$ Later the book entered popular culture. In 1974 Portela, one of the main "samba schools" in Rio de Janeiro, made it into the theme of its presentation in the great Carnival parade; a movie based on the novel was successful domestically and shown in Paris and New York; Macunaíma became a play in $1977 .{ }^{5}$ Despite its formal daring and its association with a movement that is often identified with a predominantly intellectual acceptance of "modern" social, economic, cultural phenomena, Macunaima, like other texts in literatures of nationality, is a critical adaptation that integrates an external discourse into the fabric of national life. Its reworking into other media and other levels of discourse shows that it has not become, like other modernist texts, just the symbol of a historical moment. ${ }^{6}$

Macunaima may be acceptable because it is as nationalistic in its reference as it is modernistic in its referent, answering one more time, under new conditions of economic and cultural dependence, the newly urgent need for a literature of nationality. Like the romantic texts of José de

${ }^{4}$ Haberly stresses the negative reception (Three Sad Races, p. 145), but he also shows the importance of the text and its positive contemporary reception (p. 146). "Talented nonsense" are the words of João Ribeiro, one of the friendly early readers (see "Macunaíma: Herói sem nenhum caráter-por Mário de Andrade," in Mário de Andrade, Macunaíma, p. 345).

${ }^{5}$ See Macunaima, pp. 428-37, for reproductions of paintings, of the theme song from the carnival parade, of an ad for the movie in Paris, of production and casting of the movie, of a photograph from the theatrical production.

${ }^{6}$ Neil Larsen analyzes the relation of Macunaima as literary text to its various adaptations to mass media and its relation to European modernism, on one hand, and a Brazilian popular substratum, on the other. Popularization is problematic because, though it uses the colloquial language register of the book to crack open a difficult text that left alone would "keep the masses at arm's length," it risks a "'romanticization' of the mass consumer" (criticized by Theodor Adorno) and opens the way for the "commercialized exoticisms" of Brazilian movies produced under the state-supported Embrafilme (Modernism and Hegemony, p. 90). The relation to European modernism is problematic because although Andrade, according to Larsen, escaped the double bind of a "dependent" discourse, which must claim independence and separate identity in terms supplied and controlled by the dominating culture, he might have just run into a blind alley. In Macunaima, says Larsen, Andrade "seeks to undermine the very categories of an estranging, ethnographizing Reason-race, natural environment, level of technical development, and such-whereby cultural domination is made to appear rational," by asserting, in a discourse taken from ethnography, "the informant's worldliness" and, in a wily maneuver, by "appropriating the entire discursive field" (p. 85). But as we shall see, his success is in a way indirect, negative. For an analysis of the movie, see Robert Stam, Subversive Pleasures, chap. 4, pp. 122-56. 
Alencar, whom Andrade saw as his forerunner, the modernist Macunaima accomplishes a revaluation of "national subject matter. ${ }^{\text {"7 }}$ It integrates a tradition of opposition to literary forms associated with external domination internally accepted. If the romantics, writing within half a century of their country's independence, saw themselves as opposing the (Portuguese) colonial power, which till then had determined the political, economic, and cultural life, the modernists opposed a different and more diffuse source of domination and adduced different elements as characteristic of a national identity.

The concern with national identity was not abandoned in Brazil between the romantics and the moderns; it was part of the adaptation of other literary movements to the Brazilian scene, accompanying national and international shifts in political and economic power. Aluísio Azevedo's novel $O$ cortiço (The tenement, 1890), which finds the primeval mud where Zola's human masses arise on the outskirts of an expanding Rio de Janeiro, is not only a study in the accumulation of capital, but also a meditation on the viability of what it posits as characteristically Brazilian features-sensuality, hybridness (of African, Amerindian, and European), and closeness to nature-within a global economy. In Lima Barreto's Triste fim de Policarpo Quaresma (Sad end of Policarpo Quaresma, 1911) the hero is placed in an insane asylum for trying to live like one of Alencar's ancestral Amerindians, then tries to develop Brazilian agriculture with North America machines and techniques, and is finally defeated by a characteristically national combination of insects and politicians. Both novels give greater play than Alencar to the African element in national identity. In both novels a pessimistic strain, present, as we have seen, even in Alencar, proposes a problematic view of national difference and reminds the reader of continued dependence on an external economic and cultural power. This awareness of outside pressure on the assessment of its nature and its value leads to a certain instability in the determination of national character, persistently redefined in oppositional terms.

When Mário de Andrade took Macunaíma for his hero, the primitive-preferably African-had been fashionable in Paris for about a decade, in terms similar to that of the exotic American one century earlier. African carvings and bronzes were admired in Parisian museums; prominent Frenchmen traveled to the tropics with their baggage

${ }^{7}$ See Proença, Roteiro de "Macunaíma," pp. 43-46, on common features of Alencar and Andrade. 
of French culture and carried back the tropical exotic. Raul Bopp tells about Paul Claudel's diplomatic visit to Rio in 1917, in the company of the composer Darius Milhaud. Delighted with the tropical city, they filled the embassy with exotic plants and parrots given them by their astonished Brazilian friends, and Milhaud made the popular song " $\mathrm{O}$ boi no telhado" (for which he paid no royalties) into "Le boeuf sur le toit," charming with catchy rhythms and playful dissonances. Soon, Bopp reports, both sides of the Atlantic "narrated an imaginary Brazil with colorful landscapes, like a land of utopia," and "the Brazilians who went to Paris on their vacations began to like that cordial 'Brazil' in all its primitive freshness" (Movimentos modernistas, pp. 14-15). When they returned, these travelers brought back a new valuation of "national" characteristics that had been treated with great distrust by those who, like Azevedo, implied that it was precisely its preference for the pleasure of the senses over their control and its proximity to unmediated nature which kept the nation economically and culturally dependent. At the Week of Modern Art, then, much of the work presented and of the theory behind it was concerned not only with the renewal of artistic forms which was part of modernism but also with a rethinking of the meaning of nationality and a revaluation of its distinctive characteristics.

The specifically literary movement the young modernists fought against and replaced, "paranassianism," ${ }^{8}$ had proposed regularity in literary form and universality in subject so Brazilian artistic production could merge into production from elsewhere. Even when they treated patriotic subjects, the paranassians took the classic literary language of Portugal as a model. ${ }^{9}$ Their bid for parity employed tactics of camouflaged and infiltration rather than confrontation.

\footnotetext{
${ }^{8}$ The name of the movement is taken from that of a group of French poets "whose works were collected in anthologies called Le Parnasse contemporain, issued in three phases, in 1866, 1871, and 1876," among them Théophile Gautier and Lecomte de Lisle, who opposed the romantics with a neoclassical poetics of rigorous, "perfect" forms (Afrânio Coutinho, Introdução, pp. 203-4). The French movement petered out by the 1880s, but its influence continued into the new century in Brazil (Haberly, Three Sad Races, p. 100).

${ }^{9}$ Pierre Hourcade notes that the paranassian movement was very concerned with linguistic purity, meaning conformity to standards set by Portugal, and that it had "no true national content" (Reflexions sur la poésie," pp. 62-63). Not quite so. The sonnet-of course-“Língua portuguesa" (Portuguese language) by Olavo Bilac, strongest of the paranassians, defines the language as the "last flower of Latium" and mentions only Camões as having written great works in it but, between these two high-culture references, calls nothing but natural phenomena to describe it, except for one comparison to a tuba and a lyre, products of human ingenuity, and
} 
But the moderns used other means for other ends. Oswald de Andrade was, at the time, the most notorious of the rebels. His "Manifesto antropófago" (Anthropophagist manifesto), published in the same year as Mário de Andrade's Macunaima, for a while defined the aims and methods of the movement. The manifesto, says Bopp, presented itself as "a descent to the genuine, still pure origins of the nation, which would capture the germs of renewal, repossess the subjacent Brazil . . . and strive to reach a specific cultural synthesis, with greater emphasis on national consciousness" (p. 64). Oswald de Andrade returns to an identification of contemporary Brazilian national character with the Amerindian past, but he uses it in a new way to oppose the imposition of a European culture on Brazil: instead of rejecting European culture, he proposes to incorporate it, literally, as cannibals did Europeans. Rather than identify cannibalism with Christianity, as Alencar did, or place cannibalism at the opposite pole to civilization, as did the conquerors, Oswald de Andrade proposes to solve the problem of the other as self by forcing an identity between them. He also tries in this way to wrench the consumable exotic-the Brazilian, the Amerindianaway from the centers of consumption by consuming the consumers. ${ }^{10}$ So, with monumental jokes, he debunks or demythifies grandiose concepts of nationalism based on a Europeanizing culture: he proposes as a patron saint for Brazil the-historical-Bishop Pero Sardinha (Sardine), eaten by coastal cannibals when his ship sank off the shore of Pernambuco, and as the most important national holiday October 11, the day before Columbus's landing and the last day of freedom for the Americas.

one invocation of a mother's voice speaking in it to her child. He even claims that the language has the "aroma / of virgin forests," an odd way of celebrating the language of an admired European civilization. Such observations, however, have no place in a polemic discourse that aims to disengage a new literary movement from the one that precedes it. As Haberly notes, "The Modernists loathed Olavo Bilac's Parnassian verses," though, as he adds, they intended to "accept his vision" of Brazil's characteristic ethnic composition, in the famous phrase, the mingling of its "three sad races" (Three Sad Races, p. 129). On the other hand, Mário de Andrade himself recalled that, ecstatic over the paintings of Anita Malfatti, exhibited during the Week of Modern Art and bringing news of cubism to a group of young intellectuals who knew the French impressionists but had somehow missed Cézanne, he penned "a sonnet in a most parnassian form" celebrating a work titled The Yellow Man. See "O movimento modernista," in Aspectos da literatura brasileira, pp. 231-55, 232. ${ }^{10}$ Larsen sees "Antropofagia" as an attempt, frustrated in the end, to define for a dependent economy a form of "consumptive production," a narrative form that "suppl[ies] the representational conditions for the practice of 'language' that dissolves all texts-all productions-in the identity of its own process as continuous consumptive production" (p. 84). 
He not only accepts the need for a patron saint, however, he also, in his earlier call for "a literature for export," accepts the concept of literature as a consumer product: nationalism, and even the eventual return to the cannibals, should produce something desired by the rejected European culture and must, therefore, consider the tastes of a target market. ${ }^{11}$

Mário de Andrade was not one of the anthropophagists, but critics and the reading public quickly connected his novel, in which an Indian antihero represents Brazilian authenticity with the literary manifesto that took cannibals as models for intellectual endeavor, ancestors of present-day Brazilians, and sources of a desired difference from other cultures. Despite disclaimers and a growing disaffection between the two writers, Mário de Andrade often found himself working in the same vein as Oswald, since he too was embarked on the production of a recognizably Brazilian literature defining a recognizably Brazilian character at a particular historical moment. Reappraising the movement twenty years later, Mário de Andrade himself characterized it as an effort to create a national culture: "Manifesting itself particularly in the arts, but also staining established social and political customs with violence, the modernist movement announced, prepared, and to a great extent created a national state of mind." The new literature was to address not only the Brazilian situation but also the changes it reflected in the rest of the world, brought about by "new political ideas, the new speed of transportation, and a thousand and one other international causes ... the internal progress of technology and education," and so on (Aspectos, p. 231).

Thus, a common perception of the need to define national culture within a world economy-expressed in various forms of discourseled to different strategies. Oswald de Andrade placed national literature on the international market, while Mário de Andrade turned toward an internal audience and, like Macunaíma (who refused to ask the government for a grant to study art in Paris), made it a point never to leave Brazil. Yet even if he was less concerned about the insertion of Brazilian literature into the class of phenomena called world literature (compris-

${ }^{11}$ The call for a literature for export appeared in the "Manifesto da poesia pau-brasil" (Brazilwood poetry manifesto), Correio da manhā, 18 March 1924. The "Manifesto antropófago" (Anthropophagist manifesto) was first printed in the Revista de antropofagia, year 1, no. 1 (May 1928). Andrade datelines it "'Piratininga' [the Indian name of São Paulo], Year 374 of the Swallowing of Bishop Sardinha." Both manifestos are reprinted in Oswald de Andrade, Obras completas, 6:5-10, 13-19. 
ing those works that are "legible" outside the boundaries of cultures where they are produced), he looked to the international literary movements of his time for a language to frame a definition of nationality. Despite differences in methods and personalities, Mário and Oswald de Andrade's choice of the American Indian to signify Brazilianness is, in the end, a traditional gesture among national authors. ${ }^{12}$ Once again, also, they are not only defining an internal phenomenon but also purveying exotic fare, for which outside interest has opened the internal market. Those Brazilian friends of Claudel's who provided him with tropical plants and parrots and those traveling Brazilians who, in Paris, became enamored of their own primitive, unspoiled, redemptive, and hopeful country, were participating in a recurring exchange of cultural goods and values between the less and the more powerful.

Mário de Andrade was aware that primitivism is not a representation of reality but a language. In a letter to the critic Tristão de Athayde, he explains that he uses the "primitive" not because he wants to recreate a state he cannot authentically claim, since he is a cultivated man, and not because he wants to use it specifically as a marker of difference but because he is at the beginning of a process: that of defining a Brazilian culture distinct even from that of countries such as Russia, in which an exportable literature is relatively new: "I am primitive because I belong to a beginning phase." ${ }^{13}$ Primitivism, in this argument, becomes a value-free category, purely descriptive. He also claims that his technical innovations are attempts to systematize what has already been formed in Brazil, that they do not create but reflect a reality (linguistic and other) of which writers and other intellectuals have not yet become entirely aware because they have been too preoccupied with whether Brazilian productions measure up to or are sufficiently distinctive from European ones. In other words, he claims for his work an independence from current literary trends which parallels the independence he wishes for his country but which his very intellectual development, his library, his friends' trips to Paris for inspiration and verification must deny.

With his primitive heroes, his revolutionary language, and his claims

${ }^{12}$ Antônio Cândido, in "Literature and the Rise of Brazilian National Identity," notes that regardless of the literary school they belong to, Brazilian writers have always considered it part of their function to address the problem of national identity. See also Haberly, Three Sad Races, 129-30, on the modernists' return to the Amerindian as emblem of national identity.

${ }^{13}$ See in Cartas de Mário de Andrade, the letter of 23 December 1927, pp. 16-17, 22. 
of isolation and independence Andrade creates a useful fiction from within which he can speak his nation; it is a little like the useful fictions of isolation which allow scientists to study certain phenomena in their laboratories. Rather than turn his eyes on the world and try to adapt its offerings to a Brazilian reality defined as insufficient and incomplete, he looks on what Brazil has to offer in isolation. He claims that this entity Brazil, which he tries to capture, has already produced a typical idiom to express a typical reality and that he is just tapping a flourishing and till-then neglected popular culture, not out of a desire to abandon his intellectual formation but in order to give a more accurate account of the level at which the differentiating elements of nationality are to be found. His explanations privilege the linguistic element, which is programmatically subjected to reevaluation: "When I started to write wrong Portuguese, didn't I immediately announce that I was making a Brazilian grammar, with which announcement I simply intended to show that I was not improvising, but doing something thought out and systematic?" (Cartas, p. 21). In his reasoning, the opposition right/ wrong appears with its values reversed and comes to stand for the political dichotomy between national and alien, as well as for the logical dichotomy between random and systematic: the positive value of rationality is attributed not to traditional criteria for judging literature and language but to their revaluation.

His reversals of customary evaluation do not affect all dichotomies in the same way-system and rationality are positive, as is "wrong" grammar-and this may be one reason why Mário de Andrade had to spend so much effort dissociating himself from the more anarchic procedures of Oswald de Andrade and his group, who favored a more straightforward concept of primitivism, of its authentic presence in Brazil, and of how well it represents Brazilian culture. In the end, Mário de Andrade's work on language and on the integration of popular culture into learned discourse had the same abrasiveness and destructiveness as that of the anthropophagists; at the time, however, it too could be mistaken for a fall into chaos rather than an attempt at a new, subversive order.

Meanwhile, both authors appropriated the European rebellion against received forms and turned it into a sign of nationalistic affirmation. As a rebellion, it promised a language free from compromise with established internal or external powers, in which to redefine national reality. But it also depended on those same structures to establish the scope and orientation of its opposition. In Macunaima Mário de Andrade at- 
tempts to evade the dilemma: he uses Indians and the language of exoticism to characterize Brazilianness, but his work redefines the enterprise by changing the way in which the customary signifiers of nationality are used. He recodifies the relation between an authentic national expression and the language of exoticism, to confront the problematic relation between a national character, defined as unique, and the ethical or aesthetic paradigms, which, though not unique, guarantee the intelligibility and legitimacy of such a definition because they are current and established.

But the enterprise proves problematic once again, insofar as exoticism is a category in the discourse of power. If, as Oswald de Andrade proposes, exoticism is not only the way in which the more powerful speak of the less powerful but an opportunity for the latter to enter the international cultural market, it is not, for all that, free of market pressures. In a sense, Mário de Andrade cannot define primitivism to suit his purpose, because, beyond the reach of his ability to reform Brazil's literary language, primitivism as the exotic has been enrolled in a more powerful discourse. One could say that he attempts to do from within the language of exoticism what Cooper, in Notions of the Americans tried to do from without, that is, to appropriate a language. But that language was not innocent, and he could not avoid the problem of how to articulate difference or identity, even for internal consumption, within an already established set of meanings and values.

So in Macunaima Mário de Andrade turns exoticism on its head. By following very closely the collection of tales about Macunaíma, a trickster figure of the Taulipang people, published by Theodor KochGrünberg in Vom Roroima zum Orinoco, he models his discourse on the discipline of ethnology, which claims to be scientific and thus objective and value-neutral. His Indian protagonist appears not as a representative of primitive virtue who will redeem a tired and corrupt civilization-like Alencar's heroic Indians-not, that is, as the carrier of values arbitrarily imposed from the outside but as a malicious innocence redefined into enlightened provocation to make a tired and corrupt civilization more aware of itself. His values, if any, are not derived from an extraneous discourse to fulfill an extraneous need. Macunaíma is free of the European-imposed and Brazilian-accepted load of virtue of villainy which burdened previous literary Indians; he is the prototype for a recognizable national character that defines itself not as either in conformity with or in opposition to some European model but as characteristically undefinable. As Darcy Ribeiro implies, continuing in the 
subversive vein mined by Andrade, Macunaima results from a centuriesold "game of blindman's buff," during which "the strange people seen by Columbus and Americo [Vespucci] turn into" diverse American nationals, while those who remained there-on the other side of the Atlantic-"cobble together new-worldly utopias" with elements of "our healthy and gentle savagery." In turn "we ape them and they mimeticize us," until all definitions of identity are destablized; at that point Macunaíma becomes a universally recognizable privileged representation of that nonidentity (Utopia selvagem, p. 31). ${ }^{14} \mathrm{~A}$ "hero without any character," as Mário de Andrade calls him in the subtitle, Macunaíma subverts any ontological, moral, psychological, or literary order. At the same time, the refusal to define character as centralized subject, whether psychological or social, and the introduction of immotivation into the vocabulary available for the presentation of literary characters are distinctively modernist strategies of opposition to their predecessor texts. Once again, as in the case of the early novelists of nationality, one can invoke the zeitgeist and mention not only French enthusiasm for the primitive but also that Robert Musil's Mann ohne Eigenschaften was being written at the same time as Macunaima. ${ }^{15}$ What distinguishes Mário de Andrade, however, is that instead of denying influence, he showed that acceptance, even incorporation, can be a form of criticism; if the foreign must be used to define the national, acknowledging transposition can become a form of nationalization and can indicate that the affirmation of nationality is itself a traditional and characteristic Brazilian activity, inevitably paradoxical.

In part this conjunction of the new and the traditional in Mário de Andrade's work was as important for its acceptability as the author's personal position in a group of artists who, well placed in the local social hierarchy, exercised their recognized and accepted role as revolutionizers and revitalizers of the intellectual landscape. They prepared the way for the intellectual acceptance of the change from an agrarian

${ }^{14}$ In this "fable," Ribeiro tells the adventures of a hapless, cheerful, sensual mulatto soldier in a fantasy Brazil, both historical and futuristic, with variations on themes from Macunaima. The hero ends up in an Indian tribe on a flying island (there are enough mentions of Swift to place its identification beyond conjecture), ruled by a Caliban and two ecumenical nuns; readers are also treated to the blueprint of a utopian government in a Brazil ruled by a multinational computer called Prospero. ${ }^{15}$ According to Haberly, Mário de Andrade was trying to formulate not the absence but the excess of qualities, the juxtaposition of racial and cultural components in himself and in the Brazilian national character which precluded the coherence and unity necessary for an intelligible definition of nationality (Three Sad Races, 137-38, 146). 
to an industrial economy, the growth of the cities and shift of population, the influx of immigrants. All these promised to reopen the possibility, probably not as visible since independence, of Brazil's assumption of a more prominent position in the international concert of nations. This integrative function operates whether Mário de Andrade is for or against the changes it entails: because Macunaima incorporates the phenomena of change and raises the problems they cause, it is pivotal in the development of Brazilian literature and, more generally, in the development of a language in which the country can speak of itself in its new garb.

The thread from which Macunaíma's adventures loosely hang is his voyage from the small Indian village where he was born to São Paulo and back, in a loop whose squiggles and curlicues cover most of the Brazilian territory. At first he is simply fleeing hunger, like so many inhabitants of rural Brazil; later he is on a quest for the magic stone given him by the woman he married, which he has lost. The flight, when Macunaíma and his brothers abandon their home, beset by famine and discord, eventually becomes subsumed in the quest, enabling Andrade to transport his hero from north to south without making him a refugee: what he seeks is valuable, but what he abandons is not valueless. Throughout, Andrade refuses to establish hierarchies. Macunaíma lives in a world of leveled values which embraces all the regions of the country, all their people and stories, all events and decisions.

Macunaíma marries a spirit of the forest. After giving him much pleasure and a child who dies, she is sucked dry by a snake and climbs into heaven. The magic stone she had given him ends up in the hands of a capitalist and adventurer who cooks spaghetti sauce with human meat, carries the vaguely Slavic-Italo-American name of Venceslau Pietro Pietra, and like many immigrants, lives in the industrial city of São Paulo. But Pietra is also the giant Piaimã of Amazonian Indian mythology, and he becomes a synchretic figure, a Euro-cannibal who erases the long-elaborated essential difference between the civilized and the barbaric.

In his quest for the stone, Macunaíma is like a traditional hero of epic and folktale, ${ }^{16}$ except that he does not have the usual heroic qualifications. At the inception or climax of any action, bellicose or romantic he

${ }^{16}$ In an extended analysis of Macunaima in the terms Vladimir Propp used to study Russian folktales, Haroldo de Campos demonstrates Andrade's fidelity to the form of the Taulipang myth. See Morfologia do "Macunaima." 
is as likely as not to yawn, "I feel sooo lazy," and go to sleep. ${ }^{17}$ He lacks the spirit of enterprise that promises progress: he pursues his enemy only fitfully, and does what he can to avoid meeting him "man to man" by dressing up as a French prostitute or by sending in a surrogate (chap. 6). When he meets a monster, he flees, sensibly but most unheroically. He eats too much and is cheerfully incapable of resisting any temptation of the flesh. When forced to fight, he resorts to ruses, but even so, he is one of the more vincible figures in literature. He is a trickster of flickering cleverness and innocent malice, charming, guileful, unpredictable, irresponsible, stubborn, lewd. One could not derive from him anything like a traditional literary character, or from his motives and actions anything like a code of preferred behavior. On the contrary, he negates the steadiness, reliability, and goal orientation necessary to achieve the kind of success that depends on hard work and delay of gratification, and so his laziness becomes a challenge to the power that has imposed work and accumulation on those who did not want it or think they needed it. Macunaíma is of many minds, and follows them all, challenging also traditional notions of character, plot, causality, and verisimilitude. He throws into question the qualities needed for success as defined in the world that calls him primitive. At the same time, his subversion of literary and conceptual categories falls into a known category. He is a modern antihero, though he has been transposed into the primitive mode. The primitive, however, is once again being defined as the known category thought to capture the essence of the New World.

In this double characterization as primitive and modern, Macunaíma is not a model but an instance; he redefines the primitive as neither noble nor redemptive; he is not Adam before the Fall but the unsayable id. He also dribbles past more recent associations attached to the antihero, for he is not in opposition to well-known literary figures but an alternative to them. He is not an anti-Peri; he leaves Peri behind. He is not the hope of a tired and disillusioned civilization that can find renewal, because it can still find itself, in denial; he denies the point of that civilization. His antics do not foreground the problems of good

\footnotetext{
${ }^{17}$ Larsen notes that this refrain "not only 'proves' that [Andrade] . . . has read Paulo Prado's Retrato do Brasil, but invites speculation that all such texts, however vainly they may insist on their own 'scientific' detachment, are really nothing more than the same pensée sauvage that they deludedly believe they have domesticated" (p. 85). Paulo Prado's (1926) is one of the many books that seek to identify the causes of Brazilian backwardness. See Larsen, p. 110 n. 14.
} 
and evil, of conformity to tradition or freedom acquired by experimentation on the borders of the acceptable or imaginable; they evade those problems. Macunaíma does not do what is good or evil, what will make him progress or remain backward; he does what will get him into or out of trouble, what will bring him pleasure, cause him pain, or throw him into danger.

He is born as aware of his surroundings as Oskar in The Tin Drum; with just as little childlike innocence, he seduces his sister-in-law by turning himself from an insufferable brat at home into a gorgeous young man in the forest (she gladly suffers beatings from her husband to protect her pleasure with little Macunaíma). Later, when he is wandering in the forest with his brothers, he kills, more or less by chance, a monster who is threatening a young maiden. ${ }^{18}$ When the monster's head pursues him to offer its everlasting magical services, he flees ignominiously and never hears the offer. Macunaíma is not noble and courageous; he is not a defender of helpless women, though some random action of his may have the random effect of protecting one of them; he does not uphold the values of the family; he is not even alert enough to profit from magic help when it turns up. Yet because his actions are so random that occasionally they have the same results as those of the noble hero or produce the same rewards, they break the symmetry of opposition; they configure an attempt to define otherness as independent of an extraneous, self-defined self. The remedy Macunaíma would offer to a tired Western civilization is not recourse to its own neglected virtues; he brings to the growing metropolis of São Paulo no higher morality of a simpler life. Quite simply, he will not be used.

The episode with Vei, the sun (chap. 8), contextualizes Macunaíma's otherness in literary and ideological terms. He finds himself in one of the classic fairy-tale trial situations: he is promised wealth and one of the sun's daughters for a wife if he stays on a little island off Rio and keeps away from women for one whole day while the sun goes on her round. He complies for a while, then becomes restless, goes out to explore the city and falls in, and into bed with, a Portuguese fishwife, recently immigrated. Caught, he loses his chance of making something of himself, of harnessing the tropical sun. From there on, the sun punishes him and, at several other points in the tale, mercilessly burns his back. The passage can be read allegorically: incapable of delaying

${ }^{18}$ This episode can also be read as a lethal parody of Peri's transformation from subjugated domestic to king of the Brazilian forest and protector of Ceci. 
gratification, innocent in the pursuit of sensual pleasure, ready to yield to the appeal of the best but also the most undemanding that the former colonial power can offer him, Macunaíma shows some of the most charming and also some of the most destructive traits generally attributed to the Brazilian character. Therefore, he forfeits the opportunity to become as successful as (geographically and sensually) temperate heroes, who are so ready to question the values of alternative (and tropical) cultures. Macunaíma loses his chance to make the tropical sun work for his advancement and justifies the association of the tropics with irresponsible backwardness. In this reading, the conjunction of the Iberian heritage and the merciless sun condemns him to a handto-mouth existence, narrated in his eventual return from the developed city of São Paulo (whose development is thus also thrown into question) to the Amazonian forest, where he dies. ${ }^{19}$ The allegorical reading, however, disregards the surface texture of the tale. The wit of the writing; the image of Macunaíma covered with bird droppings, washed and put to dry by Vei on the island off Rio; the zest with which the hero explores the city and "plays" with the fishwife; and the implication that the condition imposed by the sun is unreasonable counterbalance the regret at the lost opportunity and confirm the value of Macunaíma's refusal to play the game of "order and progress. ${ }^{\text {"20 }}$ The chapter seems to deny that this positivistic motto, which graces the Brazilian flag, expresses either the reality or the authentic aspirations of the nation.

Macunaima subverts the usual order of things not only by shuffling hierarchies and values but also by blurring the boundaries that help organize thought and identity. In line with Brazil's traditional view of itself as a place of exemplary race relations, where differences in color are absorbed into a multihued national culture, ${ }^{21}$ Macunaima blurs the

${ }^{19}$ Telê Ancona Lopez gives a very similar allegorical interpretation in "A margem e o texto," pp. 40-41. For reasons slightly different from mine, Haroldo de Campos rejects this reading (p. 239).

${ }^{20}$ The motto "order and progress" reflects the convictions of the young army officers who in 1889 deposed Emperor Pedro II and proclaimed the republic. It has become shorthand in a long ideological debate about the principles that define national identity and the goals and methods that should rule the nation.

${ }^{21}$ Once again there is reference to this pervasive view of race relations in Brazil, best known at this time in the formulation of Gilberto Freyre's Casa grande e senzala and contested in more recent sociological studies of racial relations in Brazil, such as Octavio Ianni's Raças e classes sociais no Brasil. Haberly says that Andrade casts doubt on the optimistic view from the vantage point of his own "racial multiplicity" (Three Sad Races, p. 143). For present purposes it is important only to note the presence of an ideology of racial harmony. 
distinctions between the races. Unlike the earlier novels of national identity, however, Macunaima does not treat the subject of contact within the marriage plot. Though the affair with his sister-in-law touches the incest motif of the other fictions and his various couplings with the Portuguese woman and the Polish girl who receives the African god Exu in a trance touch the vexed question of exogamy (since the hero belongs to all races, all his couplings are radically exogamic), these matters appear fleetingly. Macunaíma is lusty, but his only marriage dissolves, and his only child dies. The creation of a future population is none of his concern; he belongs to a population already there and already mixed.

Macunaíma is born black, "son of the fear of the night" (p. 7), into an Indian village; his first adventures take place in the forest, amid Indian myths. Then a bath in a magic pool makes him white and turns his brother Jiguê's skin copper-colored, but his second brother, Maanape, remains black because the other two used up all the magic water (chap. 5). In Macunaima the races that make up the population have the same family origin; differences, though consequential, are accidental. Interactions, even if not peaceful, are matter-of-fact: it is with the help of the African spirit Exu, temporarily inhabiting the young Polish woman, that Macunaíma wins his first victory over the giant Piaimã (chap. 7). In this episode Andrade completes the cycle through which his hero is made to encompass all races: the scene presents a characteristically Brazilian religious synchretism that integrates contributions from all populations. Macunaíma's ritual transformation refers to a characteristically casual treatment of race and reaffirms one of the most emphatically stressed Brazilian values. One notes, however, that when he bathes in that magic pool, Macunaíma becomes not just white but tall and blond, as is the woman receiving the African spirit: Andrade's text registers the common Brazilian self-characterization as a nation where all races are equal and equally respected, while the details of his representation contradict this central privileged message. By illustrating the ideology of racial harmony, Macunaíma accords with part of the reality of the composition of Brazilian national consciousness; in the choice of terms expressing this accord, however, Andrade incorporates observable data that contradict the ideological representation. The clash between ideal and reality is as much as part of what is characteristically national as are the clashing elements. At the same time, this layering of contradictory references functions like the figure of Pietra-Piaimã, to deconstruct exoticism by removing it from system of simple oppositions between primitive and European. 
In Alencar's work the violence of the contact between different people in the Americas becomes a rhythmic throb in the background, like the noise of kettledrums in a romantic symphony; in the foreground, like the strings, are virtuous and heroic Indians. When Macunaíma goes to Exu, however, he does not show or acquire virtue-just effectiveness. Violence surges and then turns into satire. A description of extraliterary reality changes into a tool of literary expression. When Exu, the African trickster god, possesses the young woman of Polish origin, Macunaíma feels a great urge to take part in the rite. He "plays" with the woman while she is in a trance and thus becomes the "son" of Exu. Then he joins the line of petitioners asking favors of the god in the woman: a butcher wants customers to buy his tainted meat (granted), a lover asks that his girl be given a teaching job so they can marry (granted), a farmer wants his farm freed of ants and malaria (not granted), a doctor asks for the ability to write elegant Portuguese (not granted). The witty formulation of these matters just barely keeps under the control of satire the cruelty of rape and dishonesty.

This leveling of values, demythification of the hero, and deromanticizing of the exotic coalesce when Macunaíma asks Exu to make Venceslau Pietro-Pietra/Piaimã suffer. The trickster god transports the giant into the medium's body, where he is thrashed and tortured till Exu himself cries out and the woman lies half dead on the ground. At intervals, the narrator repeats: "It was horrible." Finally, a modified, vaguely sacrilegious recital of the Lord's Prayer restores Exu and the woman to health, while the giant lies on the floor of his palace, howling, gored and beaten, burned and cut, bleeding and foaming at the mouth. Exu leaves, and Mário de Andrade, who had once attended such a ceremony with friends, puts a list of their names in the book and replaces his own with Macunaíma's. ${ }^{22}$

Blurring boundaries between races, religions, literary and extraliterary reality, author and creature, Mário de Andrade tries to characterize an independent otherness. The violence he invokes at these boundaries makes it difficult to accept this otherness as redemptive of the discomforts of the familiar; it also re-estranges the exoticism of a romanticized New World, unmasking it as a familiarized and tamed otherness. The specific ingredients of the anarchic stew he concocts are a recognizable part of everyday Brazilian life, and the satire that spices it serves to link it to a reality with which readers are familiar and of which they can be 
expected to disapprove. But the violence of the incidents described and their satirical intention also work against the movement toward internal exoticism which Bopp mentions, and make the typical into a source of discomfort more than a reason for pride. Thus Macunaima questions even the affirmation of national identity which underlies its own creation.

A similar estranging integration results from the "degeographication" of which Mário de Andrade speaks in his prefaces to Macunaima. ${ }^{23}$ The hero's origins and adventures make geographical boundaries irrelevant to the definition of national character. Macunaima is born somewhere in the Guianas, and his opponent Piaimã is from somewhere else: in the Taulipang myth his name means "stranger." The spirits who help and annoy the hero are from anywhere in South America or Africa. His heritage, as promised by Vei (but not delivered), is, as in the Brazilian saying used to deconstruct sophistication, Europe, France, and Bahia ("Oropa, França, e Bahia" [Macunaima, p. 67]). The language of his tale contains many words of Amerindian origin, Africanisms, Gallicisms, Anglicisms, and regional expressions from everywhere in the country in such a linguistic riot that a reader, while recognizing all as Brazilian and delighted at finding childhood words that were lost in the homogenization of schools and standardized writing also finds it difficult to read the specialized vocabulary of his fellow Brazilians' childhood words. The three great spheres of Macunaima's activities-the forest, the countryside, the city-are independent of national boundaries. They coexist, as in the domain of the giant Piaimã, whose house is an urban palace in the middle of a rural sylvan grotto developed by an English company in the city of São Paulo.

On one hand, degeographication is an expansive force that allows Macunaíma to chase and be chased throughout Brazil, from forest to town to field in one paragraph, madly galloping through the folktales, customs, and idioms of the entire country. On the other hand, it is centripetal, showing the possibility-at a time when the first great push for industrialization was concentrating in São Paulo a mad jumble of people from the entire world and from all levels of technological development-of an integration of disparate elements, creating a modern version of the traditional view of Brazil as a place where integration is possible.

${ }^{23}$ These prefaces were written at the time of the book's publication but not published until they were collected by Marta R. Batista et al., in Brasil, pp. 289-95. 
But this sort of unification is also corrosive, since, closing the circle opened with the invention of the nation one century before, it refuses to base its notion of nationality on the easy patriotism that derives pride and identity from more or less arbitrary national borders. At the only clearly official, patriotic gathering Macunaima attends, he displaces the designated orator, tells an Indian tale immediately accepted by the public, and subverts the occasion by replacing univocal, official symbols such as the flag with "natural" multivalent signs such as the constellation of the Southern Cross (which, however, also appears on the positivist Brazilian flag). Though from the official point of view the abolition of geographical boundaries and the subversion of patriotic occasions introduce disorder into the body politic, within Macunaima the dissolution of these expected distinctions begins to establish a more appropriate basis for a feeling of national affiliation. The play with political boundaries also calls into question the position of the nation in the world: relations, including (or especially) relations between nations, depend on boundaries, and unstable boundaries, like Macunaíma's laziness, disconcert power.

More tellingly, Andrade blurs the accustomed boundaries between nature, as in the New World, and culture, as in the developed West. He deromanticizes the primitive, which becomes emphatically not a redeemer of the discontents of the civilized world but an ill-mannered claimant to the voice and power of "civilization." The primitive Macunaíma guards against the excesses of government power or the evils of a nationalism that turns more or less accidental geopolitical boundaries into matters of pride and criteria for definition; he reinforces the ideals of racial equality on which his nation had always prided itself and through which it had claimed a moral superiority to those nations that based their sense of superiority on preserving the races distinct and legitimated their economic domination by it. Macunaíma integrates the national territory as no other literary creation had done and offers a way out of the fragmentation of national literature by competing regionalisms, each claiming to be representative. His motives and actions are always both savage and ignoble.

Given this superoppositional otherness of Macunaíma, it remains to be seen how the urban primitivism he inaugurates redefines urban modernity. In his treatment of the relation between Macunaíma and technology, Andrade conflates some of the terms in which other works in this vein trace the boundaries between nature and culture, on one hand, and between history and myth, on the other. What will Macunaíma do 
when confronted with the superior technological sophistication of those who affirm their power over the new nations by providing them with guns, internal combustion engines, and telephones as necessities of civilized life?

He might have remained pure by refusing them, but refusal is a solution generally chosen by refugees from civilization, not by those with whom they take refuge. In São Paulo, Macunaíma meets with technological progress at the center of economic power and sees the signs of economic development which Brazil will have to take on as it claims parity with and affirms its difference from a world that would define it. Unwilling to deny the reality of Brazil's desire for parity and unable to force the truth by denying the desirability of the products of technology, Andrade undermines their importance by attacking them at the point of production and making their magic accessible to Macunaíma as magic. When Macunaíma finds out about taxis and telephones and the need for money other than the load of cacy (cocoa) he had brought with him from the Amazon, he takes possession of this new world by turning his brother Jiguê into whatever gadget he happens to need at the moment: "He turned Jigue into the machine telephone, called up the giant Piaimã and called his mother names" (p. 44). He turns his brother into the "machine taxi" when he needs transportation, or conversely, he looks up to the "machine moon" in the sky. Just as he can technologize nature, he naturalizes technology and asks the Englishmen who own the whiskey, gun, and ammunition orchards to give their trees a shake for him (chap. 5). Magic and nerve provide Macunaíma with the products of civilization. By making primitive magic produce telephones and trees produce guns, Andrade abolishes distinctions between nature and culture and erases the history that mediates between the son of the forest and the giant of the industrialized São Paulo.

But there is a rub. Despite his magic and his ability to make the Englishmen shake guns and whiskey out of their trees for him, those trees are still not his, and in the end the episodes do not abolish history but recall it. He too is incapable of resisting the lure of European weapons and firewater. Thus he remains outside of a historical process in which he could, at least to some extent, dictate the language that speaks him. All that remains open to him is the power of use over those artifacts. ${ }^{24}$ By subjecting machines to Indian magic and referring to the

${ }^{24}$ Larsen posits consumption as affirmation, but magic is not part of a Marxist vocabulary. Mário de Andrade is as perceptive as Larsen sees him, but bitterer. 
"machine moon," he eliminates the distinction that had defined his position within the realm of the powerless and demands a revaluation of the world. Since he cannot require that revaluation from the powerless position he occupies, however, Macunaíma becomes a fantasy of possibility, rearranging the world through the imagination. The anarchy that is his medium proves incapable of functioning as a principle of government and interpretation, unable to anchor an order of political and epistemological meanings, though it can remind its readers that the arrangements they are asked to take for granted are not facts of nature, and it can make differences imaginable. Macunaíma subverts by the imagination; he has the nerve to posit a different arrangement from that which makes him perpetually exotic.

At the end of the book Macunaíma finally beats the giant in a Rabelaisian scene that ends with him swinging madly from a liana in the giant's entrance hall and the giant falling into his own spaghetti sauce, where he melts with a multitude of other ingredients into a unified soup. Macunaíma wins back his stone and returns to the place of his birth, but his victory is no apotheosis. Back home his friends are gone, he is hungry, the sun beats on his back. His brothers and his women die. He knocks on the doors of various forest spirits seeking shelter and company and is refused until one of them finally takes pity on him and turns him into a constellation, an arbitrary design imposed on amorphous eternity.

There remain telling and writing. Chapter 8 , close to the middle of the book, consists of a "Letter to the Icamiabas," written by Macunaíma, who titles himself emperor, to his "subjects" who in São Paulo are known by the more classical Hellenic name of Amazons. The letter is written in an archaizing Portuguese whose satiric intention is given away by a phonetic Brazilianism in the title (pra instead of para as it is officially written and pronounced), and it inverts the conditions under which Caminha's letter to the king of Portugal was sent. Like Caminha, Macunaíma describes the charms of the women he encounters, but they are the women of the big city, French prostitutes who demand lobster and champagne and deplete his treasure, forcing him to appeal to his subjects for more cocoa to be changed into money at a very unfavorable rate. The diction, which imitates classical Portuguese, jumbles together the centuries between the discovery and the present; it is punctured with anachronisms and Brazilianisms that question its adequacy to the present and to a separate Brazilian culture by shifting back and forth between classical antiquity and Amerindian myths, presented as equiv- 
alent but not synonymous. The letter thus questions all four centuries of writing the New World, beginning with the first document of discovery and colonization. With its description of industrial São Paulo to the Icamiabas and with its demands for products of forest extraction to pay for French prostitutes in the most developed economic center of the nation, the letter also inverts the discoveries and restates relations of economic dependency. It translates disparities in economic and cultural power between Brazil and Europe into disparities between the "savage" and the "civilized" wherever they appear, but it promises that the helpless subjection of the savage leads to the inevitable subversion of the civilized. At the end, Macunaíma observes that the people of the city have the strange habit of speaking a barbarous but vital language but writing a different, "Camonian" one, the language he is using in his own missive. But the missive is a parody, and since the Icamiabas may be illiterate, it is destined not to be read, breaking the loop of American writing upon which from the times of the first accounts, both subjection and independence had been predicated.

There remains at the end of Macunaima a storytelling parrot who wanders off into the distance, on the shoulder of a man to whom it spins the tale of Macunaíma, transposing language from the realm of culture into that of nature so the story can be told to us. This is the innovative, revolutionary language Mário de Andrade invents for his work, incorporating the vocabularies of the many nations that form Brazil, respecting a popular native syntax and, because he is a cultivated man, as he always admitted, transforming it into a new, flexible, expressive, recognizably Brazilian literary language recovered for writing.

In the trajectory from parrot to narrator to text, Macunaima asserts cultural independence from the former colonial power, which till then had dominated the former colony's mode of expression, if not its economy, and opens the way for the possibility of expressing a critical view of the world which subverts the customary perception of national reality. Like Alencar, who began by forging a "Brazilian" language, Mário de Andrade finds in language the final and lasting affirmation of his work. In it man and parrot, culture and nature, join in the creation of the anarchic Macunaíma, who, if he does not solve the problems of exoticism, of domination, of economic and cultural dependency, finally becomes part of what is understood as Brazilianness by creating a different articulation of all these problems. He enters a national mythology in this now-basic text of Brazilian literature not only by redefining national identity in terms of disjuncture and incoherence but also by positing a 
different relation between the discourses of a powerful self and an other defined as dependent. In this novel the absence of power proves subversive and destablizes the discourse of power without replacing it. In this way, it affirms the interdependence of definer and defined, center and margin, neither term of which is intelligible without the other. Essential to this decentralization and deconstruction is Andrade's refusal to make an exception for his own discourse: a parrot is a doubtfully adequate symbol for oppositional or differentiating speech.

Having mounted his radical attack on the discourse of power, however, Andrade feels free to inhabit it, and just as Cooper and Alencar used the forms of romantic fiction to challenge the distribution of discursive power between former metropoles and former colonies, so Andrade uses the modernist idiom for a similar and still necessary challenge. The result of the adaptation he performed was not the affirmation of an identity whose contradictions battled an overarching vision of national identity as coherent and stable; it was, rather, a vision of all identity as fragmented, all structure as unstable, that is, fictitious, and of a Brazilian national identity finally relevant within the discourse of power only insofar as it embodies the destruction that this discourse suspects it carries within itself. Bakhtin called this relation between stability and corrosion, center and margin Carnival. ${ }^{25}$ Having carnivalized their own carnival into a huge tourist attraction for the developed world, Brazilians are amused. Macunaíma, rewriting Chactas, would probably roll on the ground with laughter.

${ }^{25}$ Robert Stam refers to Mikhail Bakhtin's "Forms of Time and of the Chronotope in the Novel" in his analysis of Brazilian film. The movie Macunaima and Brazilian film in general, he contends, carnivalize Americanization, especially Hollywood. See Subversive Pleasures, pp. 122-56. 